\title{
STUDI ISLAM DAN MASA DEPAN ISLAM
}

\author{
(Telaah Pemikiran Fazlur Rahman)
}

\author{
Shofa Robbani \\ Institut Agama Islam Sunan Giri Bojonegoro \\ E-Mail: shofa@sunan-giri.ac.id
}

\begin{abstract}
"This paper deals with Islamic studies and the future of Islam. Firstly, Fazlur Rahman considers that neo-modernists have acknowledged that Western civilization is the only alternative for the future of the world. He revealed a fact that modernity in the West, ethics, and law is able to develop as an independent discipline with secularism method. On the contrary, Islamic ethics was never developed as an independent discipline based on the systematic interpretation methodology of the Qur'an. Secondly, Rahman mentions the orthodoxy of Islamic thought on the obsolete methodology, such as qiyās, must be reconstructed with a new methodological approach, such as maslahat, so that, the elasticity of Islamic law is able to provide solutions to all contemporary problems. In addition, Rahman highlighted the impact of the hegemony of Western civilization on the mindset and lifestyle of Muslim communities that can be seen in a variety of new situations that are full of complexity. Actually, he wants to create synergy between Muslim and non-Muslim intellectuals and can work together between them. In discussing the development of Islamic intellectualism, he said that something that was desired primarily was to understand the Qur'an with the historical background and new interpretations."
\end{abstract}

Keyword: Islamic studies, modernization, Islamic thought, Fazlur Rahman.

\section{Pendahuluan}

Islam menyeru seluruh umat manusia untuk saling mengenal, hal ini didasarkan bahwa mereka semua berasal dari satu nenek moyang, yaitu Nabi Adam 'alaih al-salam. Islam menganggap persaudaraan umat manusia sebagai satu keluarga. Bahkan, Islam menjadikan tujuan diciptakannya manusia adalah agar mereka saling mengenal. Allah Swt. berfirman, "Hai manusia, sesungguhnya Kami menciptakan kalian dari seorang laki-laki dan seorang perempuan; dan Kami menjadikan kalian berbangsa-bangsa dan bersuku-suku, supaya kalian saling mengenal. Sesungguhnya orang yang paling mulia diantara kalian di sisi Allah ialah orang yang paling taqwa. Sesungguhnya Allah Maha Mengetahui lagi Maha Mengenal.” (Q.S. Al-Ḥujurāt:13).

Ayat di atas menjadi dalil bahwa Islam menolak segala bentuk konflik yang bersifat semena-mena antar kelompok, golongan, suku dan etnis. Islam tidak membeda-bedakan antara mereka yang berkulit putih dengan yang berkulit hitam; antara etnis yang kaya dengan etnis yang miskin; kelompok penguasa dengan kelompok rakyat. Islam menentang sikap fanatisme 
golongan dan menolak upaya sukuisme sebagai parameter mengukur keutamaan dan kemulyaan dalam pandangan Islam. Selain itu, ayat di atas juga mengandung dalil bahwa Islam menyeru untuk mempelajari peradaban dan agama, hingga terbangun koalisi bersama dalam mewujudkan kemaslahatan dan melawan kemudaratan. Allah Swt. berfirman, "Tolongmenolonglah kalian dalam (mengerjakan) kebajikan dan takwa; janganlah kalian tolongmenolong dalam perbuatan dosa dan pelanggaran; dan bertakwalah kalian kepada Allah! Sesungguhnya Allah Maha Pedih siksaan-Nya.” (Q.S. Al-Māidah:2).

Koalisi seperti yang dijelaskan dalam ayat di atas merupakan hal terpuji yang diserukan oleh Rasulullah Saw.; sebagaimana Beliau sabdakan, "Aku pernah menghadiri sebuah perjanjian di rumah Abdullah bin Jad'an; perjanjian yang menurutku lebih baik dari pada unta merah (kekayaan terbaik). Seandainya hari ini, aku diundang untuk melakukannya pada masa Islam, aku pasti akan memenuhinya. "1 Hadis ini, memberi pengertian bahwa Rasulullah Saw. mengisyaratkan adanya peristiwa "hilf al-fudul" yang terjadi sebelum beliau diutus menjadi Nabi dan Rasul. Dalam perjanjian hilf al-fudul itu, semua pihak mengikat perjanjian untuk senantiasa menolong orang-orang yang terzalimi dan mau mengembalikan hak-hak yang terampas kepada pemiliknya.

Islam merupakan agama pertama yang berusaha membangun hubungan sangat luas dengan menyerukan perdamaian global. Hal ini dipertegas oleh seorang orientalis Barat yang bernama Bernard Lois tatkala dirinya menyatakan bahwa peradaban Islam terbentang luas melintasi benua Asia, Afrika, dan Eropa. Menurutnya, peradaban Islam telah memulai upaya pembangunan peradaban yang multi etnis, budaya, bahkan lintas benua. Peradaban Islam terbentang luas melampaui batas yang pernah ditorehkan oleh dua kebudayaan besar, yaitu Romawi dan Yunani. Dengan begitu, peradaban Islam telah bersinggungan dengan bagianbagian penting dari berbagai peradaban maju kala itu, hingga menyebar di wilayah Asia, kemudian mengadopsinya dan membungkusnya dengan nilai-nilai Islam.

Oleh karena itu, Umat Islam saat itu sangat giat menyerukan upaya saling mengenal antar peradaban dan dialog antar agama guna mewujudkan persatuan umat manusia, yaitu masyarakat global yang diserukan oleh Islam. Karena koeksistensi antar bangsa bisa terwujud melalui sikap saling mengenal dan saling tolong-menolong dalam kebaikan, bukan dalam kejahatan dan permusuhan.

\footnotetext{
${ }^{1}$ Abd. Al-Rahman al-Suhaily, Al-Raḍ al-Anffí Tafsir al-Sïrah al-Nabawiyyah li Ibn Hishām, Vol. 2 (Beirūt: Dār al-Kutub al-'Ilmiyyah, 2009), 244.
} 


\section{Shofa Robbani}

Peradaban Islam yang sempat memimpin dunia tidak mampu bertahan selamanya. Seperti halnya roda kehidupan yang selalu berputar, maka begitu juga yang terjadi pada peradaban Islam yang sudah sangat maju terus berputar dan saat ini serasa berada di pusaran bagian tengah atau bawah. Kemajuan studi Islam yang sudah mapan berangsur-angsur terpuruk sejak terjadinya pengepungan di Baghdad, Irak yang terjadi pada 1258, peristiwa invasi dan penghancuran kota Baghdad, Ibu kota Kekhalifahan Abbasiyah ketika itu dan merupakan Ibu kota Irak era modern, oleh pasukan Ilkhanate Mongol bersama pasukan sekutu-sekutu mereka di bawah pimpinan Hulagu Khan. Tujuan utama ekspedisi Hulagu ke Timur Tengah adalah untuk mendirikan imperial kokoh (kini Toluid) yang mampu mengendalikan daerah ini dan memperluas kekaisaran, namun tidak secara langsung menggulingkan Abbasiyah yang sebelumnya telah tunduk kepada mereka. ${ }^{2}$

Begitupun demikian, intensitas sekuler-demokrasi yang digembor-gemborkan oleh media Barat telah membawa pengaruh pada kebangkitan Islam dan munculnya sekte Islam Fundamentalisme. Sekuler-demokrasi sebagai alat pencitraan Barat modern selama kurun abad kesembilan belas hingga era neo modernitas saat ini menurut Fazlur Rahman memberikan pengakuan bahwa peradaban Barat tampaknya menjadi satu-satunya alternatif untuk masa depan dunia. Jika tradisi lain yang timbul bukan dari peradaban Barat atau tidak mau sepenuhnya digantikan oleh Barat, maka mereka harus menjalani transformasi radikal jika tetap keukeh ingin survive. Untuk alasan inilah, menurut Rahman, Barat dianggap telah berhasil indoktrinasi ke benak masyarakat dunia.

Suatu peradaban memiliki tradisi yang syarat dengan budaya, hal ini terkadang sengaja dipelajari sebagai bagian dari akulturasi budaya oleh ahli geografi Muslim dan sejarawan budaya. Motivasi dari studi mereka - ahli geografi Muslim dan sejarawan budaya- yang jauh dari kontroversial literatur agama Islam telah melahirkan rasa keingintahuan dan pencarian informasi, motif ini diperkuat oleh desakan Al-Qur'ān yang mendukung adanya perintah keliling dunia untuk tujuan pendidikan.

Pada dasarnya, studi semacam ini tidak merendahkan dan juga melecehkan golongan mana pun. Tujuan semacam ini, jelas berbeda dengan motivasi yang berasal dari Barat modern yang mengklasifikasikan bahwa mempelajari Islam dan masyarakat Islam adalah hal yang berbeda. Dalam beberapa kasus, rasa keingintahuan dan petualangan tentu menang, tapi, menyisihkan motif sadar imperialistik dan citra diri dari peradaban barat merupakan syarat dari

\footnotetext{
${ }^{2}$ Peter Jackson, "The Dissolution of the Mongol Empire," Central Asiatic Journal Vol. 3 No. 2 (1978), 186-243.
} 
visi pembawanya kepada masyarakat muslim, bahkan mengubur alam bawah sadar mereka untuk mengkonfrontasi antara keduanya.

Sebuah analisis brilian dari fenomena ini, meskipun kadang-kadang terkesan tendensius dalam karakterisasinya, disajikan oleh Edward Said dalam bukunya yang berjudul Orientalism. Namun, yang menjadi kekhawatiran Rahman bukan dampak dari kajian para orientalis terhadap Islam, namun yang ia cemaskan adalah hilangnya motivasi kajian ke-Islaman di Barat, dan diganti dengan efek utama mereka, yaitu dari segi persepsi Barat tentang Islam dan citra diri kaum muslimin. Rahman, dalam tulisan makalah ini, mencoba untuk memproyeksikan masa depan Islam, dan mulai dengan menganalisis laporan tentang pembukaan, yaitu, bahwa sampai saat ini penciptaan tradisi adalah tugas eksklusif pembawanya.

\section{Fazlur Rahman}

Fazlur Rahman lahir pada 21 September 1919 di Distrik Hazara, Pakistan dan meninggal pada 1988. Ayahnya, Mawlana Shihab al-Din, adalah seorang alim (teologyurisprudence Muslim) yang mendapat pendidikan di Deoband, India. Meskipun Fazlur Rahman tidak belajar di Darul Ulum (tempat ayahnya belajar waktu itu), namun ia menguasai kurikulum Dars Naz̧amy yang ditawarkan lembaga tersebut dalam kajian privat dengan ayahnya. Ini melengkapi latar belakangnya dalam memahami Islam tradisional dengan perhatian khusus pada Fikih, Ilmu Kalam, Hadis, Tafsir, Mantiq, dan Filsafat. ${ }^{3}$

Di bawah bimbingan ayahandanya, Fazlur Rahman memperoleh pendidikan dalam disiplin tafsir, hadis, fiqih, kalam, dan falsafah. Pernyataan-peryataannya mengenai reformasi dan tulisan-tulisannya telah menimbulkan reaksi keras dari pihak tradisional, yang mendorongnya untuk meninggalkan Pakistan pada 1968. Kemudian ia menduduki jabatan profesor di Universitas Chicago, USA dan mengabdikan diri pada pendidikan dan penelitian sampai akhir hayatnya. ${ }^{4}$

Diantara faktor yang mempengaruhi pemikiran keagamaan Fazlur Rahman adalah ketekunan ayahnya dalam mengajarkan agama dengan disiplin tinggi, sehingga dia mampu beradaptasi dengan berbagai macam peradaban dan tantangan di dunia modern, disamping juga pengajaran ibunya terutama tentang kejujuran, kasih sayang, serta kecintaan sepenuh hati darinya. ${ }^{5}$

\footnotetext{
${ }^{3}$ Gunawan Ikhtiono, Pendidikan Nondikotomik Fazlur Rahman (Yogyakarta: Kaukaba, 2014), 33.

${ }^{4}$ Abdou Filaly Ansary, Pembaruan Islam: Dari Mana dan Hendak Ke mana, diterjemahkan oleh Machasin dari Réformer l'islam: Une introduction aux débats contemporains (Bandung: PT. Mizan Pustaka, 2009), 210.

${ }^{5}$ Fazlur Rahman, "An Autobiographical Note” Journal of Islamic Research, Vol. 4, No. 2 (Oktober, 1990), 227.
} 


\section{Shofa Robbani}

Menurut Syafi'i Ma'arif, Fazlur Rahman termasuk salah satu pemikir neo modernisme yang paling serius dan produktif dalam mengkaji pembaruan Islam. Sebagai orang yang pernah langsung berguru kepada Rahman, Syafi'i Ma'arif memasukkan Rahman sebagai seorang tokoh intelektual Muslim yang memiliki latar belakang keilmuan yang unik. Hal ini karena Rahman memiliki latar belakang tradisi keilmuan yang berseberangan, yaitu keilmuan pendidikan di madrasah Pakistan yang tradisional konservatif waktu kecil hingga pendidikan magister dan keilmuan di Barat yang liberal saat jenjang doktoral hingga mencapai gelar Guru Besar. Dua latar belakang yang berlawanan itu sangat berpengaruh dalam membentuk intelektualismenya. Ma'arif menyebut dalam diri gurunya terkumpul ilmu seorang 'alim yang 'alim dan ilmu seorang orientalis yang beken dan liberal. ${ }^{6}$

Setelah memperoleh pendidikan dasar dari ayahnya, Fazlur Rahman memulai sekolah modern di Lahore pada tahun 1933. Selesai dari pendidikan ini, ia melanjutkan ke Universitas Punjab dan lulus dengan gelar Bachelor of Arts (B.A.) pada tahun 1940 dalam spesialisasi Bahasa Arab. Dua tahun kemudian, ia meraih gelar magister dalam bidang yang sama dari kampus yang sama. Merasa kurang puas dengan pendidikan di negerinya, pada tahun 1946 Rahman berangkat ke Oxford University, Inggris untuk melanjutkan studi doktoralnya. Rahman menulis disertasi tentang psikologi Ibnu Sina di bawah bimbingan Prof. Simon Van Den Bergh yang kemudian diterbitkan dengan judul Avicenna's Psychologi. ${ }^{7}$

Fazlur Rahman giat mempelajari bahasa-bahasa Barat sehingga menguasai banyak bahasa. Paling tidak, ia menguasai Bahasa Arab, Urdu, Persia, Turki, Inggris, Latin, Yunani, Perancis, dan Jerman. Karena banyaknya bahasa yang dikuasai, ia juga sempat mengajar beberapa saat di Durham University, Inggris. Selanjutnya, dia pindah dari Inggris ke Kanada untuk menjadi Associate Professor pada bidang studi Islam di Institute of Islamic Studies McGill University, Kanada. ${ }^{8}$ Setelah tiga tahun di Kanada, akhirnya Fazlur Rahman kembali ke tanah air dan memulai proyek paling ambisius dalam hidupnya, yaitu mendirikan Institute of Islamic Research dengan dirinya sebagai direktur dan memprakarsai penerbitan Journal of Islamic Studies yang hingga kini masih terbit secara berkala dalam taraf Internasional.

Lembaga riset rintisan Rahman ini menerapkan strategi ganda dalam upaya menjadikannya lebih kompetitif, yaitu memadukan pengetahuan umum dan agama sehingga terintegrasi menjadi satu kesatuan yang utuh. Tujuan utamanya adalah membentuk pemikir

\footnotetext{
${ }^{6}$ Ahmad Syafi'i Ma'arif, Fazlur Rahman: Al-Qur'än dan Pemikirannya dalam Islam, Edisi Indonesia (Bandung, Pustaka, 1984), vi.

${ }^{7}$ Sibawaihi, "Implikasi Pemikiran Ketuhanan Fazlur Rahman terhadap Pendidikan Islam", dalam Usman, Pendidikan Islam: konsep, Aksi, dan evaluasi (Yogyakarta: Fakultas Ilmu Tarbiyah dan Keguruan, 2010 ), 7.

${ }^{8}$ Abuddin Nata, Pemikiran Pendidikan Islam dan Barat (Jakarta: Rajawali Press, 2013), 316-317.
} 
yang kuat religius sekaligus memiliki kecakapan dalam bidang ilmu umum dan modern. Di samping menjadi direktur pada lembaga riset tersebut, Fazlur Rahman juga diangkat menjadi direktur pada Advisory Council of Islamic Ideology pemerintah Pakistan pada tahun 1964. ${ }^{9}$

Di antara karya-karyanya yang diterbitkan, dapat disebutkan:

- The Philosophy of Mulla Sadra Sadr Al-Din al-Shirazi (Albany: State University of New York Press, 1975).

- Islam (Chicago: The University of Chicago Press, 1979).

- Major Themes of the Qur'an (Minneapolis: Bibliotheca lslamica, 1980).

- Muhammad: the Educator of Mankind (London: Muslim School Trust, 1980).

- Islam and Modemity: Transformation of an Intellectual Tradition (Chicago: The University of Chicago Press, 1982).

- Revival and the Reform in Islam: A Study of Islamic Fundamentalism (makalahmakalah yang dikumpulkan dan diberi kata pengantar oleh Ebrahim Moosa) (Oxford: One World, 2006). ${ }^{10}$

Fazlur Rahman adalah satu dari banyak pemikir Muslim kontemporer yang mengakui pendekatan ilmiah modern dengan mempertahankan faith secara intensif dan mendalam. Untuk dapat menggabungkan dua sikap ini, ia mengajukan diri untuk membangun sebuah visi Islam yang murni, dengan menggunakan pemahaman yang lebih baik terhadap pengalaman Nabi, kondisi-kondisi historis dan politik yang di dalamnya pengalaman itu terjadi, dan transformasitransformasi yang diusahakannya untuk tercipta dalam masyarakat. Kesadaran Rahman terhadap pendidikan sebagai sarana utama penunjang pembaharuan, inilah yang mendorongnya terjun dalam kritisme sistem pendidikan Islam yang berkembang pada periode kemunduran dan pada awal pembaharuan (modern). ${ }^{11}$

Pengetahuan tentang momen-momen pertama Islam menurut Fazlur Rahman mempunyai peran yang sangat besar. Sebenarnya, yang dimaksudkan adalah suatu jenis pengetahuan yang sangat khas, yang berusaha untuk menghindari dua jalan ekstrem yang samasama merusak: jalan ekstrem menutup diri dalam lingkaran ortodoksi tertutup, yang luput menganggap yang esensial, dan jalan berlindung di dalam objektivitas ilmiah, sehingga menjadi tidak mampu mencapai yang esensial dari kebenaran-kebenaran adikodrati iman.

\footnotetext{
${ }^{9}$ Ummu Mawaddah dan Siti Karomah, "Relevansi Pemikiran Fazlur Rahman Terhadap Pendidikan Modern di Indonesia", Jurnal Al-Thariqah Vol. 3, No. 1 (Januari-Juni, 2018), 19.

${ }^{10}$ Abdou Filaly Ansary, Pembaruan Islam: Dari Mana dan Hendak Ke mana, 211.

${ }^{11}$ A. Mas'adi Ghufron, Pemikiran Fazlur Rahman tentang Metodologi Pembaharuan Hukum Islam (Jakarta: Raja Grafindo Persada, 1997), 23.
} 


\section{Shofa Robbani}

Fazlur Rahman telah menghasilkan sejumlah artikel penting dan Sumbangan ilmiah dalam karya-karya kolektif. Kebanyakan dari tulisan-tulisannya ditulis dalam bahasa Inggris, Ia dulu menjadi penanggung jawab dari lembaga kajian agama (Islam) yang paling penting di negerinya dan mesti menghadapi reaksi-reaksi keras dari pihak ulama dan fuqaha ketika ia menerbitkan karyanya yang berjudul Islam, terutama karena konsep-konsep yang dikembangkannya berhubungan dengan wahyu. Pada akhirnya, ia terpaksa meninggalkan jabatan-jabatannya dan mengungsi ke Amerika Serikat, tempat ia melanjutkan riset-risetnya di Universitas Chicago. Karyanya nyaris tak terbaca oleh publik Arab dan Islam, meskipun dikenal luas di dunia Barat. Dengan penguasaan ilmiahnya, imannya yang mandalam, ketajaman dan ketepatan analisisnya, Fazlur Rahman benar-benar merupakan salah satu figur paling penting dalam Islam masa kini yang pemikirannya layak untuk dikaji.

\section{Teologi dan Hukum Sebagai Induk Disiplin Ilmu}

Studi Islam, sebagaimana diuraikan oleh sarjana Muslim abad pertengahan, dikelola melalui sistem madrasah, bergandengan tangan dengan perkembangan intektualisme Islam yang dibentuk dengan sistem pendidikan yang lebih tinggi. Secara umum, hukum dan teologi Islam membentuk kernel dasar ilmu-ilmu syariat dengan tafsir teks-teks suci Al-Qur'ān dan hadits sebagai yang kedua, dan beberapa ilmu lainnya sebagai yang ketiga.

Pada mulanya disiplin ilmu filsafat dan ilmu pengetahuan diajarkan sebagai disiplin intelektual murni di banyak pusat kajian pendidikan, kemudian dijadikan sebagai kurikulum. Namun, pada abad pertengahan menjadi termarginalkan dan terjadi degradasi secara drastis pada kajian filsafat dan science hingga mereka yang masih bertahan benar-benar dianggap tidak ada (counted for nothing). Kecuali dalam Syi'ah Iran, di mana kajian filsafat tumbuh subur dan mencapai titik tertinggi pada abad ketujuh belas. Mistisisme tidak pernah menemukan jalan dalam sistem pendidikan resmi, dan karenanya, mistisisme menciptakan untuk dirinya sendiri tempat di pusat-pusat kajian tasawuf. Meskipun hal itu bukanlah hal yang aneh bagi calon sarjana Muslim (ulama) untuk belajar disiplin konservatisme di madrasah dan juga mendaftarkan diri sebagai murid dari Syaikh Sufi baik secara simultan dengan atau setelah pendidikan madrasah mereka. Di Abad Pertengahan Islam, kajian tafsìr dan ḥāshiyah tafsìr, ilmu retorika dan ilmu seni berbicara (eloquence) menjadi semakin menonjol, sehingga begitu banyak analisis linguistik yang timbul dari Al-Qur'ān secara harfiah beralih pada minat substansinya.

Pernyataan di atas senada dengan apa yang pernah Rahman tulis dalam monografinya yang berjudul Islamic Education and Modernity dan pada batas tertentu dalam Theology and 
Law in Islam (Second Levi Della Biennial yang diedit oleh Gustave van Grunebaum). Rahman mencoba untuk menunjukkan bahwa meskipun kalam Teologi diklaim sebagai pembela hukum, tapi pada kenyataannya, muncul dan tumbuh cukup independen lebih dari itu, dan dalam arti tertentu, bahkan saling bertentangan. Alasan utama kurang serasinya antara teologi dan hukum muncul dikarenakan kurangnya pengembangan etika dalam Islam, yang bisa menengahi dan mempengaruhi antara dua disiplin ilmu tersebut. Dalam konteks etika ('ilm alakhlāq) yang sudah dibukukan dalam Islam, pada kenyataanya para pengkaji ilmu etika telah melenceng dari ilmu-ilmu syariat dan telah berbelok secara eksplisit pada dua sumber, Yunani atau Persia. Ketika etika filosofis yang berasal dari Yunani memasuki ortodoks Sufi Islam melalui karya-karya Ghazali, ide-ide aliran Persia justru menemukan rumah yang lebih siap dan lapang dalam struktur ortodoks ide. Rahman percaya itu ada semacam 'bola liar' kepada afinitas Arab asli, yaitu, pra-Islam, cita-cita keadilan diungkapkan melalui maksim yang dibedakan dari bahasa Yunani yang diungkapkan lebih detail dalam hal prinsip-prinsip abstrak.

Dalam kasus apapun, etika Islam yang benar tidak pernah dikembangkan sebagai disiplin independen berdasarkan interpretasi sistematis Al-Qur'ān dengan unsur-unsur dari bahasa Yunani, Persia, atau sumber lain yang kemudian memungkinkan untuk dijadikan sebagai metodologi yang terintegrasi. Sama seperti di Kristen dimana teologi menduduki lapangan tengah, sedangkan etika itu dihasilkan dan ditunjukkan dari karakteristik etika karbitan (ersatz ethics), maka teologi tidak bisa memiliki kehidupan yang independen. Sehingga dalam Islam lapangan tengah diduduki oleh hukum, dan meskipun etika Islam itu praktis atau mungkin bisa dikatakan begitu praktis, tapi tetap saja digabung dengan hukum dan tidak muncul sebagai disiplin ilmu yang independen. Di Barat modern, etika dan hukum berkembang sebagai disiplin yang independen, mereka melakukannya dengan metode sekularisasi.

Teologi ortodoks Islam muncul akibat reaksi terhadap sekte Khawarij dan lebih khusus pada Mu'tazilah. Perkembangan hukum secara positif didikte oleh kebutuhan internal dan mengekspresikan kejeniusan orang Arab-Muslim dalam bentuk paling orisinalitas. Meskipun kecemerlangan mereka, bagaimanapun, itu adalah pintu awal dari kelemahan mendasar tertentu dan kekurangan-kekurangan lainnya. Diktum Profesor Schacht terulang dalam karyanya yang berjudul Origins of Muhammadan Jurisprudence yang menceritakan tentang perkembangan hukum Islam dan Al-Qur'ān selalu diperkenalkan pada tahap sekunder (kedua) yang memicu keterkejutan tidak hanya untuk umat Islam tetapi juga untuk semua non-Muslim, karena bukan 


\section{Shofa Robbani}

rahasia lagi kalau keyakinan Muslim dalam Al-Qur'ān adalah sebagai Firman Tuhan. Menanggapi diktum Profesor Schacht, Rahman menuturkan,

This dictum is obviously palpably wrong since whatever legislation the Qur'an had given -for example, the inheritance laws and certain penal laws- had inevitably been adopted from the very beginning. The only acceptable meaning that can be given to such a statement is that as the principle of qiyas or analogical reasoning was adopted, formulated, and became refined, the process witnessed a more thorough application of the principle to the content of the Qur'an. ${ }^{12}$

Hal ini tidak berarti bahwa Al-Qur'ān datang untuk memberikan pentingnya progresifitas yang lebih besar sebagai objek keyakinan, tapi itu derivasi hukum atau integrasi dengan materi hukum yang sudah ada menjadi lebih luas sebagai implikasi hukum dari semakin banyaknya ayat-ayat yang perlu ditelisik lebih jauh dengan metode qiyās yang murni dengan spekulasi.

Salah satu ilustrasi lain yang terkenal bahwa ketika tanah Sawād di Irak ditaklukkan oleh umat Islam di bawah kepemimpinan Khalifah Umar. Waktu itu Khalifah menolak untuk mendistribusikan tanah kepada tentara Muslim sebagai ghanima (harta rampasan perang) seperti yang dipraktekkan oleh Nabi terhadap wilayah taklukan suku-suku Arab. Terjadi gesekan serius diantara para Sahabat waktu itu akibat keputusan Umar karena sekilas menyalahi pakem yang berasal dari Nabi, yaitu Sunnah. Akhirnya, Umar muncul satu hari di depan umum dan berkata bahwa ia telah menemukan ayat Al-Qur'ān yang mendukung ijtihadnya ini, dan ia membacakan Surat al-Hashr ayat 10 yang artinya:

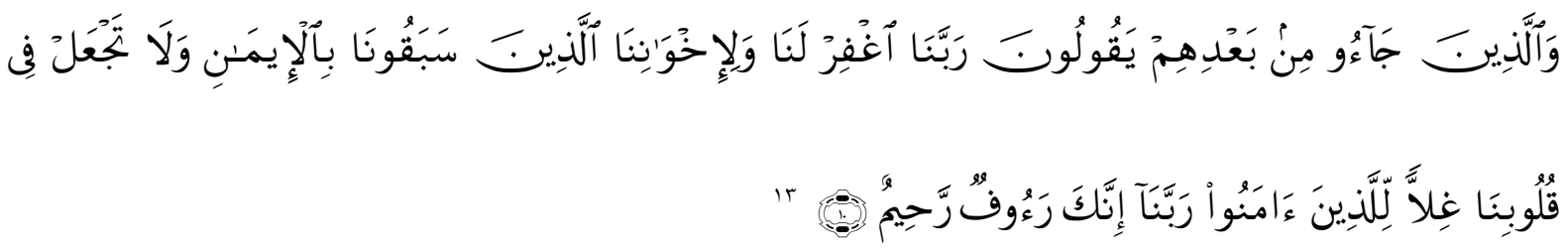

Ayat ini ia kemukakan setelah membaca ayat-ayat lain yang membahas tentang pendistribusian harta rampasan perang. Lebih lanjut Khalifah Umar mengatakan bahwa hak-hak generasi mendatang harus diingat dan dipertimbangkan juga ketika mendistribusikan harta jarahan.

Alasan kuat Umar rupanya adalah bahwa jika tanah dari seluruh negara didistribusikan di antara keluarga para tentara penakluk, maka apa yang akan tersisa untuk generasi mendatang?

\footnotetext{
${ }^{12}$ Fazlur Rahman, Islamic Studies and The Future of Islam, dalam Nur A. Fadhil Lubis, Introductory Readings in Islamic Studies (Medan: IAIN Press Medan, 1998), 234.

13 (Q.S. Al-Hashr: 10)
} 
Dalam kajian ilmu Ushul Fikih kasus kebijakan Umar tersebut dikenal dengan istilah ijtihad. Pada masa sahabat yang lebih dekat dengan tradisi kehidupan Rasulullah saw, pemecahan masalah hukum lebih banyak bersandar pada Al-Qur'ān dan tradisi yang dibawa oleh Rasul, dan mereka saling bertukar informasi tentang tradisi Rasul tersebut. Namun, semenjak timbul persoalan-persoalan baru yang menuntut ketetapan hukumnya. Untuk itu para sahabat berijtihad, mencari ketetapan hukumnya. Setelah wafat Rasulullah SAW sudah barang tentu berlakunya hasil ijtihad para sahabat pada masa ini, tidak lagi disahkan oleh Rasulullah SAW, sehingga dengan demikian semenjak masa sahabat ijtihad sudah merupakan sumber hukum. ${ }^{14}$ Apabila mereka tidak menemukannya dalam dua sumber tersebut, mereka dengan segala upaya dan kesungguhan berijtihad mencari pemecahan masalah dengan selalu mengambil inspirasi dan menangkap pesan-pesan universal Al-Qur'ān dan sunnah. Dalam berijtihad seringkali mereka menghasilkan pemecahan yang berbeda. ${ }^{15}$ Oleh karena itu, tidaklah berlebihan kalau Ibnu Khaldun, seorang sosiolog muslim yang terkenal mengatakan: "Tidaklah sahabat itu mampu berfatwa, dan tidak semua dari mereka itu dapat diambil dan dijadikan pedoman dalam agama”. ${ }^{16}$ Lain halnya di kalangan Syi'ah yang berkeyakinan bahwa para imam mereka memiliki hak otoritatif sebagaimana juga yang dimiliki oleh Rasul dalam menginterpretasikan wahyu Ilahi. Apapun yang diputuskan olehnya melalui interpretasi dan elaborasi adalah mengikat kaum muslimin. ${ }^{17}$

Penggunaan prinsip qiyās, tidak peduli seberapapun akuratnya, tetap tidak bisa memadai keadilan dari tujuan awal derivasi hukum dari Al-Qur'ān sampai tugas menentukan doktrin Al-Qur'ān itu sendiri dapat tercapai dengan cara yang memuaskan. Adapun bicara tentang kajian karakteristik Al-Qur'ān itu merupakan dua tempat yang berbeda. Di tempat pertama, Al-Qur'ān tidak dimaksudkan untuk menjadi sebuah buku hukum, itu sebabnya AlQur'ān menyebut dirinya sebagai 'guidance of mankind' (hudan li al-nass) dan menuntut manusia untuk patuh terhadap perintah-perintah-Nya. Namun, perintah ini sebagian besar tidak berupa hukum, tetapi berupa etika atau quasi-legal. Oleh karenanya, untuk menjelaskan derivatif hukum dari sumbernya, kebulatan tekad yang cukup kohesif sangat diperlukan. Ketika sarjana Muslim melihat qiyās tidak bisa diterapkan atau justru menyebabkan dampak yang memberatkan, mereka terpaksa beralih pada prinsip-prinsip tertentu dengan berbagai istilah seperti 'al-mașlaḥāt al- 'āmmah aw 'al-'adālah' yang tidak terhubung dengan prinsip-prinsip

\footnotetext{
${ }^{14}$ Muhammad Yusuf Musa, Tärikkh al-Fiqh al-Islāmy (Kairo: Dār al-Kutub al-Hadithah, 1958), 277.

${ }^{15}$ Amir Nurudin, Ijtihād Umar ibn al-Khattāb, (Jakarta: Rajawali Press, 1991), 71.

${ }^{16}$ Ibnu Khaldun, Muqaddimah Ibn Khaldun (t.t., Dar al-Bayan, t.th.), 446.

${ }^{17}$ Abdul Aziz A Sachenia, Kepemimpinan Dalam Islam Perspektif Syi'ah (Bandung: Mizan, 1991), 23.
} 


\section{Shofa Robbani}

syariat tertentu tetapi mempunyai maslahat yang lebih besar dan menyeluruh (al-Mursalah). Hasilnya adalah hukum Islam bergerak -tidak jarang- diantara kekakuan ekstrim dan kelemahan ekstrim. Jika doktrin Al-Qur'ān bisa di 'las' menjadi satu kesatuan yang cukup kohesif dengan mengembangkan metodologi penafsiran yang memadai, menghindari ketidakseimbangan dan dislokasi pada garis etika dan hukum, maka sangat memungkinkan untuk membentuk antara keduanya dengan hubungan yang murni dan terukur.

Di tempat kedua, Al-Qur'ān bukanlah buku edaran, Al-Qur'ān adalah kumpulan ayatayat yang diwahyukan kepada Nabi Muhammad selama kurang lebih dua puluh tiga tahun misinya. Ayat-ayat Al-Qur'ān, khususnya yang berkaitan dengan kehidupan sosial politik, tidak muncul kecuali ada kebutuhan untuk pernyataan atas isu-isu konkret yang dihadapi oleh Nabi dan Sahabatnya dalam kurun masa pewahyuan. Banyak dari latar belakang turunnya ayatayat ini atau yang familiar disebut dengan asbābun al-nuzūl, telah diabadikan dalam tafsir AlQur'ān . Al-Qur'ān sering memberikan keterangan secara eksplisit atas dasar pemikiran dari kandungan makna yang tersurat dari teks-teks suci. Namun, apabila tidak disampaikan secara eksplisit, maka mereka (mufassirūn) tentu sangat terbantu dengan adanya asbābun al-nuzūldari ayat tersebut. Dengan demikian, yang dibutuhkan adalah kajian komprehensif yang sistematis dari alasan-alasan ini atau tujuan dari Al-Qur'ān dalam hal prinsip-prinsip atau nilai-nilai yang akan membentuk etika dalam Al-Qur'ān . Dalam hal ini sikap Rahman adalah sebagai berikut:

Laws then could be derived from the ethics, taking due account of the necessary changes in circumstances so that the objectives of the Qur'an were fulfilled rather than it being merely, juggling with words. These objectives would embody the 'public interest' (maslaha) but this public interest would thus be firmly linked with the principles of the Shari'a rather than floating freely ${ }^{18}$

\section{Sinergisme Pemikiran Intelektual Muslim dan Non Muslim Untuk Masa Depan Islam}

Setelah mengurai tentang teologi dan hukum sebagai induk disiplin ilmu dalam Islam, fokus Rahman dalam bukunya Islamic Studies and The Future of Islam beralih pada upaya mensinergikan ilmuan muslim dan non muslim dalam kemajuan Islam melalui telaah pembelajaran sistem pendidikan abad pertengahan. Pertimbangan dalam penentuan teologi dan hukum berlaku juga untuk teologi dan tasawuf, meskipun dalam beberapa kasus, prinsip penafsiran berdasarkan latar belakang (asbābun al-nuzūi) tidak sepenuhnya berlaku. Ada

\footnotetext{
${ }^{18}$ Fazlur Rahman, Islamic Studies and The Future of Islam, 236.
} 
energi besar untuk mensistematisasi teologi Al-Qur'ān ke dalam pandangan umum. Lebih lanjut lagi Rahman mengatakan:

I am not saying that, through this procedure, only one system of Islamic law, theology, and spirituality would come into being which could claim to be mysteriously unique, but I am saying that the chaos that reigned in these fields in the medieval centuries could be either eliminated or made more manageable and certainly made genuinely conformable to the Qur'an. ${ }^{19}$

Perkembangan liar (tanpa bisa dibendung) direpresentasikan oleh kaum sufi yang sebenarnya jauh lebih tenang dalam hal teologi. Bisa dibayangkan jika adagium "pintu ijtihad telah tertutup" tidak akan terjadi. Maka sejak saat itulah gagasan-gagasan cemerlang serta pemikiran progresif seorang mujtahid baru, mampu mematahkan ketakutan dan keminderan dalam mengelaborasi ajaran Al-Qur'ān dan menjadikannya sebagai keyakinan dalam melakukan interpretasi teks-teks suci. Sehingga bisa dibayangkan kalau ilmu agama tidak akan menurun (terus berkembang) dan memberi pemahaman bahwa Islam adalah agama yang melarang kemudaratan atau hambatan yang luar biasa, termasuk dalam hal ijtihad, karena Al-Qur'ān berulang kali menekankan bahwa alam semesta ini diperuntukkan bagi kemaslahatan umat manusia dalam mempelajari dan mengeksploitasi isinya, karena itu semua merupakan 'tanda' dari kekuasaan dan keagungan Allah. Jika semua ini terdengar terlalu spekulatif dan mungkin seperti angan-angan, Rahman mengakui kalau dirinya memang telah mengundang sikap skeptis banyak orang, namun ia punya alasan tersendiri yang argumentatif. Ia menyatakan:

there is no doubt that given the methodology that I have outlined, the Character of Islamic intellectualism and of Islamic education would have been radically different. As for the methodology itself, there is nothing wrong or inherently and insuperable difficult or, indeed, un-Islamic about it; on the contrary, Islam would have come more truly and effectively into its own through this methodology than it has actually done. ${ }^{20}$

Seputar polemik validitas ijtihad adalah kajian yang menarik untuk dikaji. Secara garis besar Dr. Muhammad al-Amin dalam bukunya al-Ijtihād Baina Musawwighāt al-Inqițā wa ḍawābit al-Istimrār mengatakan bahwa perdebatan sengit di antara ulama kontemporer dalam menanggapi hal tersebut lebih dipicu dengan rancunya rumusan antara Mujtahid Mutlak yang independen (mustaqil) dan Mujtahid Mutlak yang non independen (muntasib), yang mana

\footnotetext{
${ }^{19}$ Ibid, 237.

${ }^{20}$ Ibid, 237.
} 


\section{Shofa Robbani}

keduanya sama-sama sudah memenuhi kriteria seorang mujtahid mutlak. Dari sini, maka muncullah dua pendapat;

1. Pendapat pertama mengatakan tertutupnya pintu ijtihad seiring dengan punahnya mujtahid mutlak. Rumitnya persyaratan yang diajukan sebagai tolak ukur mujtahid mutlak ditengarai sebagai penyebab dari kejumudan (stagnan) nalar ijtihad kontemporer. Maka, kelompok ini mendedikasikan pasca Madhāhib al-Arba'ah formulasi hukum baru melalui nalar ijtihad sudah tidak ada. Dan berasumsi bahwasanya Mujtahid Mutlak yang independen (mustaqil) dan Mujtahid Mutlak yang non independen (muntasib) pada hakikatnya mempunyai arti sama.

2. Pendapat kedua beranggapan sebagaimana Nabi dengan leluasa membuka pintu ijtihad, maka tidak ada seorangpun yang pantas dan berhak untuk menutupnya. Artinya, ijtihad masih akan terus exist sepanjang zaman. Kelompok ini melihat adanya perbedaan antara Mujtahid Mutlak yang independen (mustaqil) dan Mujtahid Mutlak yang non independen (muntasib). Walaupun keduanya telah mencapai kriteria yang menurut kaum utilitarian religius dianggap bentuk kasta-hirarki seorang mujtahid. Akan tetapi, dalam konteks tertentu, capaian Mujtahid Mutlak yang non independen (muntasib) tidak mampu menyamai torehan Mujtahid Mutlak yang independen (mustaqil). Semisal dalam hal perumusan-perumusan kaidah fiqh, yang menurutnya tidak mungkin pada zaman sekarang bisa menciptakan pokok-pokok landasan baru dalam mengkaji kaidahkaidah baru pula. ${ }^{21}$

Al-Jabiri dalam kitab Wijhatu al-Nadhar mengatakan: menyingkap tirai ijtihad patut dilakukan dan mutlak untuk segera disingkirkan, demi terbukanya pintu ijtihad yang perlahan tapi pasti, ditambah sikap puas umat. Namun demikian, menyingkirkan penghalang untuk melakukan ijtihad saja tidak cukup tanpa ditopang dengan membuka dan menghadirkan nalar baru ('aqlun jadid) melalui reorientasi nalar mujtahid. Tanpa menghadirkan nalar baru, kata Jabiri, mustahil menghadirkan ijtihad yang baru pula. ${ }^{22}$

Menyikapi beragamnya kebenaran inilah diperlukan 'nalar inklusif' sehingga kita tidak terjebak pada penghakiman kebenaran lainnya di luar kebenarannya sendiri. Membuka nalar merupakan langkah awal yang patut dilakukan, sehingga pintu ijtihad yang dengan rapat ditutup akan dengan mudah dibuka. Tanpa membuka nalar, maka seruan untuk membuka pintu

\footnotetext{
${ }^{21}$ Dr. Muhammad al-Amin, al-Ijtihād Baina Musawwighāt al-Inqițā wa ḍawābit al-Istimrār (Dār al-Buhūth Li al-Dirāsāt, 2003), 48-49.

${ }^{22}$ Muhammad Abid Jabiri, Wijhatu al-Nadzar: Naḥwa I'ādati Bināi Qạ̣āāā al-Fikri al-'Araby al-Mu'ạsir (Beirut: al-Markaz Al-Thaqāfah Al-‘Araby, 1992), 92.
} 
ijtihad hanyalah angin lalu saja. Ini karena pada dasarnya, ijtihad tidaklah tertutup, tapi ia akan tertutup dengan sendirinya ketika kran berfikir bebas — dengan nalar sebagai mediumnyaditutup.

Ijtihad memberikan ruang yang demikian besar pada akal, sementara peran-peran teks otoritatif diminimalkan. Ketika ijtihad diungkapkan, yang terbayang dalam benak seseorang adalah pembebasan aktifitas nalar dan pengabaian teks otoritatif (Al-Qur'ān dan Sunnah). Kesan semacam ini, meskipun tidak sepenuhnya benar, namun juga tidak terlalu keliru. Karena, ijtihad itu sendiri meniscayakan kesungguhan dalam upaya menggali, mengungkap, dan merumuskan hukum dengan menjadikan nalar sebagai mediumnya. Namun demikian, tidak terlalu benar mengatakan bahwa ijtihad mengabaikan sama sekali teks-teks otoritatif. Karena, dalam memerankan praktik ijtihad, teks-teks tersebut selalu dijadikan referensinya. Oleh karena itu, makna ijtihad penting diaplikasikan terlebih dahulu sebelum memasuki detail persoalannya, sehingga tidak mengaburkan permasalahan ini.

Selain mengupas tentang ijtihad, Rahman juga menyoroti dampak hegemoni peradaban Barat terhadap pola pikir dan gaya hidup masyarakat Muslim yang bisa terlihat dalam berbagai situasi baru yang penuh dengan kompleksitas. Pada tingkat politik, kolonialisme Barat menciptakan kebencian di antara populasi Muslim, yang hasilnya pada dasarnya negatif, bukan hanya pada tataran politik tetapi juga dalam hal reaksi pada tingkat sosial. Peralihan kolonial telah menghasilkan kondisi psikologis di kalangan umat Islam pada umumnya bahwa kemampuan mereka untuk memikirkan kembali warisan peradaban Islam dengan beberapa jarak rasional dan objektivitas dalam rangka untuk merekonstruksi masa depan Islam bisa dibilang telah rusak parah (incalculable damaged). Alih-alih mampu membuat jarak rasional vis a vis dengan warisan masa lalu, intelektual Muslim rata-rata didorong untuk melekat pada masa lalu. Seorang cendekiawan Muslim tertentu bisa mengatakan: di abad XVII dan XVIII, seorang sarjana Muslim tidak bisa mengatakan dengan impunitas hari ini. Konservatisme Muslim telah mengakar selama berabad-abad, namun berkat pemerintahan kolonial, kaum konservatisme mendapat pencerahan secara psikologis dan dasar pemikiran baru. Hal inilah yang menjadi concern Rahman kali ini untuk mewujudkan sinergisme pemikiran intektual Muslim dan Barat.

Barat dengan kekuatan kolonial politiknya tidak menjadi perhatian Rahman secara langsung disini, meskipun dampaknya pada pengembangan studi Islam dan karakter pendidikan di masyarakat Muslim dalam beberapa hal telah memunculkan kegaduhan. Titik penekanannya ada di budidaya studi Islam di Barat dan pengaruhnya, baik pada visi kajian keislaman di Barat maupun pada studi Islam di negara-negara Muslim. Kajian Kristen Barat 


\section{Shofa Robbani}

tentang Islam harus dikeluarkan dari tema masyarakat Muslim untuk alasan yang jelas, meskipun sikap Kristen terhadap Islam baru saja menjalani proses perubahan yang cukup drastis. Selanjutnya, banyak pemikir yang menulis ilmiah tentang Islam, termasuk sejarawan menampilkan pada titik-titik fanatisme apa yang mungkin menyebabkan seorang misionaris Kristen mengeras pucat.

Ketika kita membandingkan model pendekatan Kajian Kristen Barat tentang Islam dengan Kajian Keislaman tentang non Islam, maka kita akan menemukan sosok pemikir abad kesepuluh yang minat dan kecenderungannya tak luntur dengan kokohnya jeruji besi, nama populernya adalah Al-Biruni, sedangkan nama aslinya adalah Abu al-Raihan Muhammad ibn Ahmad al-Biruni. Beliau dilahirkan pada tahun 362 H (973 M) di Birun, Ibu Kota Negara Khawarizm atau lebih dikenali sebagai Turkistan. Ia dikenal sebagai filusuf yang gemar mengembara untuk mempelajari serta meluaskan dimensi ilmu pengetahuannya yang mendorong dirinya merantau hingga ke Negara India. Semasa berada di India, Al-Biruni ditawan oleh Sultan Mahmood al-Ghaznawi.

Namun, setelah menyadari keilmuwannya beliau ditugaskan di istana sebagai salah seorang ulama. Kesempatan itu digunakan sepenuhnya oleh Al-Biruni untuk mempelajari Bahasa Sanskrit dan bahasa lain di India. Di sana beliau mengambil kesempatan untuk mengenali agama Hindu dan falsafah India. Hasilnya beliau telah menulis beberapa buah buku yang mempunyai hubungan dengan masyarakat India dan kebudayaan Hindu. ${ }^{23}$

Tinjauan literatur Barat modern tentang Islam terlalu panjang untuk ditulis dalam makalah ini. Tapi Rahman tetap menyajikan salah satu contoh studi Barat pada Al-Qur'ān . Untuk saat ini, menurutnya, hampir tidak ada studi di Barat yang mengkhususkan pada substansi ajaran Al-Qur'ān kecuali pekerjaan usang yang pernah dilakukan oleh Hubert Grimme dalam dua bagian biografi Muhammad yang diterbitkan pada tahun 1895. Dan tafsir Al-Qur'ān nya Rudi Paret yang merupakan 'magnum opus'nya, ia menyajikan kaya referensi silang ayat-ayat yang mengandung sejenis atau ide yang sama. Di Barat, jika tidak, ada dua pendekatan untuk mempelajari Al-Qur'ān. Salah satunya adalah pendekatan yang berusaha untuk melacak pengaruh Yahudi atau Kristen pada wahyu Islam. Seperti Albert Hourani telah menunjukkan dalam presentasinya, filsafat Islam secara umum diperlakukan dengan cara yang sama, vis a vis, dari sumber Yunani. Tidak ada yang bisa menyangkal bahwa pendekatan ini memiliki kepentingan sejarah tertentu, tetapi juga bisa dipungkiri bahwa pendekatan ini minim

\footnotetext{
${ }^{23}$ D.J. Boilot, Al-Biruni (Beruni), Abu'l Rayhan Muhammad B. Ahmad", in Encyclopaedia of Islam (Leiden), New Ed., Vol.1:1236-1238. Excerpt 1 dalam https://en.wikipedia.org/wiki/Al-Biruni diakses 27/11/2016.
} 
dalam melakukan pemahaman Al-Qur'ān dan ide-ide yang sebaliknya, dan cenderung mendistorsi konten yang ada. Banyak dari sarjana Kristen yang cenderung untuk menemukan pengaruh Kristen pada Al Qur'an, sedangkan sarjana Yahudi banyak membuat keadaan menjadi lebih buruk dengan hanya pergi ke laut lalu bilang telah 'menemukan' tradisi Yahudi dalam Al-Qur'ān. Fenomena menyedihkan justru ada dalam karya terbaru John Wasnbrough, Qur'anic Studies, yang oleh Rahman disinggung dalam monografi singkatnya yang berjudul An Introduction to Major Themes of The Qur'an.

Pendekatan utama Barat untuk mempelajari Al-Qur'ān adalah untuk membentuk suatu tatanan kronologis dari isi Al-Qur'ān . Pekerjaan yang paling sederhana dan dapat diandalkan masih tetap Geschichte des Qurans milik Noldeke-Schwally. Namun yang paling berharap penelitian dapat dikejar menjadi kemunculan dan perkembangan dari tema dan studi Al-Qur'ān adalah pendekatan yang dilakukan oleh R. Blachere dalam hal fase psikologis kehidupan Nabi yang tampaknya bermakna atau bahkan sangat layak dan, sejauh yang dapat dikelola, itu adalah bagian dari terungkapnya tema Al-Qur'ān. Satu hal yang harus direnungkan dalam hal tujuan Al-Qur’ān dalam mengungkap tema yang berkaitan dengan psikologi Nabi sangat menarik untuk diteliti.

\section{Kesimpulan}

Fazlur Rahman dalam tulisannya Islamic Studies and The Future of Islam berkeinginan untuk mewujudkan sinergisme antara intelektual Muslim dan non Muslim dan dapat terjalin kerja sama antara keduanya. Dalam membahas perkembangan intelektualisme Islam, ia mengatakan bahwa sesuatu yg diinginkan utamanya adalah untuk memahami Al-Qur'ān dengan bantuan Asbābun al-nuzūl atau latar belakang sejarah. Kegiatan ini adalah sebagian murni sejarah dan sebagian interpretatif. Sekarang kajian sisi histori Al-Qur'ān bisa dilakukan oleh seorang sarjana non Muslim serta Muslim. Dengan beasiswa dari Barat, dengan latar belakang dan peralatan alat intelektual, Barat jauh lebih mampu melakukan pekerjaan ini dari pada beasiswa dari Islam pada saat ini. Apa yang diperlukan saat ini adalah kemauan untuk masuk ke Al-Qur'ān itu sendiri daripada hanya berkutat pada sekitaran itu, mampu terlibat dalam apa yang harus distorsi dari Al-Qur'ān pada hal-hal yang dianggap tidak relevan lagi. Hal ini semestinya adalah tugas Muslim sendiri untuk menafsirkan ulang Al-Qur’ān secara sistematis dengan bantuan hasil perkembangan sejarah mengenai tema sejarah akan tercapai.

Beasiswa pendidikan sejarah dapat dilakukan baik oleh Muslim maupun non-Muslim. Tapi saat ini, umat Islam, secara umum, tidak memiliki perlengkapan ilmiah yang diperlukan 


\section{Shofa Robbani}

dan terkesan masih tradisionalis, meskipun para pendahulunya (sarjana Muslim kurun awal) telah memberikan khazanah, bahan untuk penyelidikan sejarah, namun mereka enggan dan belum sepenuhnya menyadari akan pentingnya hal ini, bahkan mereka mengakui bahwa pada dasarnya mereka tidak mau melakukan pekerjaan ini karena takut berdosa dan inovasi berbahaya. Adapun kaum fundamentalis, ia benar-benar takut kalau usaha semacam itu akan memunculkan beberapa tesis yang paling dihargainya, karena pada isu-isu tertentu yang telah datang untuk menganggap sebagai fundamental, ia jauh lebih literalis dan jauh lebih tahan terhadap alasan daripada konservatif tradisionalis. Yang terakhir, setidaknya, umat Islam memiliki warisan yang sangat kaya akan sastra dan pendidikan di belakangnya yang memungkinkan mereka untuk menafsirkan ulang Al-Qur'ān dan tiba di solusi yang paling sering masuk akal jika tidak sistematis, dan karenanya, terkadang agak dipaksa. Kaum fundamentalis, yang telah memilih untuk turun tahta dari warisan pasca-Nabi yang kaya ini secara intelektual sangat dangkal, emosional, fanatik, dan konservatif.

Bagaimana dengan Muslim berpendidikan modern? Mungkin pada akhirnya akan diminta sebagai bentuk penafsiran Islam modern yang telah terjadi di era modern dari seorang pemikir modern. Tapi penafsiran semacam ini secara ad hoc berpusat pada isu-isu tertentu, tanpa metodologi yang eksplisit. Hal lainnya yang perlu diketahui adalah alasan sosiologis untuk orientalisme Muslim saat ini, misalnya, dengan sisa ulama 'murni' atau 'sejarawan', mereka dengan mudah dapat menghindari tugas sulit menilai masa lalu dan menafsirkan dari masa depan yang positif. Selanjutnya, ia juga menghindari oposisi seperti suatu usaha pasti untuk mengundang pada bagian dari pasukan tradisionalis. Satu-satunya obat untuk beasiswa yang dianggap steril dari berbagai kepentingan adalah dengan mencoba untuk mengganti orientalisme dengan studi Islam asli yang akan menjadi konstruktif dan tujuan baik untuk Islam dan untuk beasiswa Barat. Jika hanya harus memiliki masa lalu tanpa masa depan, maka umat Islam, dengan demikian, akan memiliki sedikit harapan untuk hidup, begitupun sarjana Barat Muslim mungkin juga gak beda jauh hanya memiliki sedikit harapan untuk hidup. 
STUDI ISLAM DAN MASA DEPAN ISLAM

\section{DAFTAR PUSTAKA}

Amin (al), Muhammad., al-Ijtihād Baina Musawwighāt al-Inqițā wa ḍawābit al-Istimrār (Dār al-Buhūuth Li al-Dirāsāt, 2003)

Ansary, Abdou Filaly., Pembaruan Islam: Dari Mana dan Hendak Ke mana, diterjemahkan oleh Machasin dari Réformer l'islam: Une introduction aux débats contemporains, (Bandung: PT. Mizan Pustaka, 2009)

Ghufron, A. Mas'adi., Pemikiran Fazlur Rahman tentang Metodologi Pembaharuan Hukum Islam (Jakarta: Raja Grafindo Persada, 1997)

Ikhtiono, Gunawan., Pendidikan Nondikotomik Fazlur Rahman (Yogyakarta: Kaukaba, 2014)

Jabiri, Muhammad Abid., Wijhatu al-Nadzar: Naḥwa I'àdati Bināi Qaḍ̂āā al-Fikri al- 'Araby al-Mu'āṣir (Beirut: al-Markaz Al-Thaqāfah Al-'Araby, 1992)

Jackson, Peter., “The Dissolution of the Mongol Empire," Central Asiatic Journal Vol. 3 No. 2 (1978)

Khaldun, Ibn., Muqaddimah Ibn Khaldun, (t.t., Dar al-Bayan, t.th.)

Ma'arif, Ahmad Syafi'i., Fazlur Rahman: Al-Qur'an dan Pemikirannya dalam Islam, Edisi Indonesia (Bandung, Pustaka, 1984)

Mawaddah, Ummu dan Siti Karomah., "Relevansi Pemikiran Fazlur Rahman Terhadap Pendidikan Modern di Indonesia”, Jurnal Al-Thariqah Vol. 3, No. 1 (Januari-Juni, 2018)

Musa, Muhammad Yusuf., Tarikh al-Fiqh al-Islami, (Kairo: Dar al-Kutub al-Haditsah, 1958)

Nata, Abuddin., Pemikiran Pendidikan Islam dan Barat (Jakarta: Rajawali Press, 2013)

Nurudin, Amir., Ijtihad Umar ibn al-Khattab, (Jakarta: Rajawali Press, 1991)

Rahman, Fazlur., “An Autobiographical Note” Journal of Islamic Research, Vol. 4, No. 2 (Oktober, 1990)

Rahman, Fazlur., Islamic Studies and The Future of Islam, dalam Nur A. Fadhil Lubis, Introductory Readings in Islamic Studies, (Medan: IAIN Press Medan, 1998)

Sachenia, Abdul Aziz A., Kepemimpinan Dalam Islam Perspektif Syi'ah, (Bandung: Mizan, 1991)

Sibawaihi., "Implikasi Pemikiran Ketuhanan Fazlur Rahman terhadap Pendidikan Islam", dalam Usman, Pendidikan Islam: konsep, Aksi, dan evaluasi (Yogyakarta: Fakultas Ilmu Tarbiyah dan Keguruan, 2010)

Suhaily (al), Abd. Al-Raḥman, Al-Rad al-Anf fi Tafsì al-Sïrah al-Nabawiyyah li Ibn Hishäm, Vol. 2 (Beirūt: Dār al-Kutub al-'Ilmiyyah, 2009) 